\title{
Oil and Fat in Broiler Nutrition
}

\section{口 Author(s)}

Baião NC

Lara LJC

Departamento de Zootecnia

Escola de Veterinária da UFMG

\section{Mail Address}

Nelson Carneiro Baião

Escola de Veterinária - UFMG

Departamento de Zootecnia

Avenida Antônio Carlos, 6627

Pampulha

31.270-901. Belo Horizonte, MG, Brasil

E-mail: baiao@vet.ufmg.br

\section{Keywords}

Broiler nutrition, fat, lipids, oil.

\section{ABSTRACT}

The terms "fat" and "oil" refer to triglycerides of several profiles of fatty acids. Fatty acids that are not bound to other organic components as glycerol are the so-called free fatty acids. Lipids constitute the main energetic source for animals and they have the highest caloric value among all the nutrients. Linoleic acid is the only fatty acid whose dietetic requirement has been demonstrated. Besides supplying energy, the addition of fat to animal diets improves the absorption of fat-soluble vitamins, decreases pulverulence, increases diet palatability, and the efficiency of utilization of the consumed energy. Furthermore, it reduces the rate of food passage through the gastrointestinal tract, which allows a better absorption of all nutrients present in the diet. The energetic value of oils and fats depend on the following: the length of the carbonic chain, the number of double bonds, the presence or absence of ester bonds (triglycerides or free fatty acids), the specific arrangements of the saturated and unsaturated fatty acids on the glycerol backbone, the composition of the free fatty acid, the composition of the diet, the quantity and the type of the triglycerides supplemented in the diet, the intestinal flora, the sex and the age of the birds. In birds, body fat composition is similar to the composition of the fat from the diet. The apparent digestibility of unsaturated fats is high in the first days of life of birds, whereas apparent digestibility of saturated fats is low. The quantity of oils or fats is assessed by the following methods: titration, moisture, impurities, unsaponifiable, saponification value, percentage of fat, percentage of free fatty acids/ acidity and the profile of fatty acids. The methods initial peroxide value, active oxygen method, osi, iodine value, and analysis of the thiobarbituric acid (TBARS) are specific to evaluate the oxidative stability. Considering diets with the same nutritive values, birds fed with rations containing oil present better performance than birds fed no oil. Moreover, the use of oil or fat in diets for broilers may change both the composition and the quality of the carcass.

\section{INTRODUCTION}

The term "fat" (animal or vegetal) is used as a synonym for lipid in the human food as well as in the ingredients for animal nutrition. The addition of fat to diets, besides supplying energy, improves the absorption of fat-soluble vitamins, diminishes the pulverulence, increases the palatability of the rations, and increases the efficiency of the consumed energy (lower caloric increment). Furthermore, it reduces the passage rate of the digesta in the gastrointestinal tract, which allows a better absorption of all nutrients present in the diet.

The terms fat and oil refer to triglycerides of several profiles of fatty acids. The fats and oils are esters of glycerol; the former are solid, whereas the latter are liquid at room temperature. 
Lipids constitute the main energy reserve of animals and it has the highest caloric value among all nutrients. The carbon atoms of the fatty acids are chemically more reduced than carbon atoms found in sugar; therefore, the oxidation of triglycerides releases more than twice as much energy as carbohydrates. The deposition of 1 $g$ of energy from carbohydrates or protein by an animal requires higher quantities of these nutrients in comparison to the deposition of $1 \mathrm{~g}$ of energy from fat. Moreover, carbohydrate and protein reserves would be larger in function of the polar characteristic of theses substances, which would include water in these deposits (Lehninger et al., 2000). Considering diets with similar nutritive value, chickens fed rations containing oil showed better performance than birds fed diets without oil inclusion (Moura, 2003).

\section{Definition of lipids}

Lipids are substances soluble in non-polar organic solvents (chloroform and ether) and insoluble in water, which can be divided into four categories: simple, compound, derived and terpenoids.

Simple lipids are esters of fatty acids and certain alcohols, particularly glycerol and cholesterol. These can be divided into three classes: triglycerides, steroids, and waxes. Triglycerides are constituted by glycerol esterified with three fatty acids and represent more than $90 \%$ of the foods used in animal feeding. Steroids are lipids that cannot be saponified, which means that heating in the presence of alkalis does not hydrolyze them; therefore soap is not produced from their fatty acids. Sterols are the most abundant steroids, and cholesterol is the main sterol of animal tissues (Ferreira, 1999). Waxes are esters of fatty acids with long-chain alcohols and constitute the natural protecting coverage of leaves, stems, insects, skin, feathers, hairs and also the structural material of beehives. They have no nutritional value, since they are hydrophobic and cannot be degraded by the digestive enzymes of superior animals (Ferreira, 1999).

Compound lipids are esters of glycerol that contain two fatty acids plus another chemical group such as choline or serine. The most important groups are the phospholipids, which contain phosphate in their structures, whereas glycolipids have one carbohydrate replacing a fatty acid, and lipoproteins, which constitute the principal means by which lipids are transported in the blood (Leeson \& Summers, 2001).

Derived lipids include substances with fatty acid, glycerol and with other alcohols that derive from simple and compound lipids after hydrolysis (Ferreira, 1999).
Terpenoids are characterized by a repeating unity, which is the isopropene. This group includes the carotenoids, xantophylls, tocopherols and vitamins A and K (Ferreira, 1999).

According to Fats (1985), the so-called free fatty acids are not linked to another organic component as the glycerol. The free fatty acids comprise a small fraction of total lipids in natural foods.

The physical and chemical properties of lipids are determined by the composition of their fatty acids, and the length and saturation degree of the carbonic chain. The term saturated means the absence of double bonds, whereas unsaturated indicates the presence of one or more double bonds. The identification and nomenclature of the main fatty acids are represented on Table 1.

Birds are not able to synthesize all fatty acids and thus, some are considered essential fatty acids. Linoleic $(18: 2, n-6)$ and linolenic $(18: 3, n-3)$ fatty acids are recognized as metabolically essential. However, the linoleic acid is the only essential fatty acid whose diet requirement has been demonstrated (National Research Council, 1994).

The increase in the length of the carbonic chain of saturated fatty acids increases the melting point of the fat and the presence of the double bond decreases the melting point. The longer is the chain, the smaller is the number of double bonds, and less soluble it will be in water. The geometry of the double bond also influences the melting point. Trans fatty acids have higher melting point than their cis isomers. The importance of knowing the fatty acid composition of each lipidic source is as fundamental as knowing the carbonic chain length, its saturation degree, and the position of the double bond. All of these factors influence the digestion process (Fats in animal feeds, 1985).

\begin{tabular}{|c|c|c|}
\hline Common name & Identification & Nomenclature \\
\hline Myristic & C 14:0 & Tetradecanoic \\
\hline Palmitic & C16:0 & Hexadecanoic \\
\hline Stearic & C18:0 & Octadecanoic \\
\hline Palmitoleic & C 16:1, n-7 cis & 9-hexadecenoic \\
\hline Oleic & C $18: 1, n-9$ cis & 9-octadecenoic (cis) \\
\hline Elaidic & C18:1, n-9 trans & 9-octadecenoic (trans) \\
\hline Linoleic & C 18:2, n-9, 12 cis & 9,12 octadecadienoic \\
\hline$\alpha$-Linolenic & C18:3, n-9 12, 15 cis & $9,12,15$ octadecatrienoic \\
\hline Arachidonic & C $20: 4, n-5,8,11,14$ cis & 5,8,11,14-eicosatetraenoic \\
\hline
\end{tabular}

\section{Lipid absorption}

The main factor that affects the metabolizable energy value of oils (Table 2 ) and fats is their digestibility 
(Table 3), which is dependent on the following factors: the length of the carbonic chain, the number of double bonds, the presence or absence of ester bonds (triglyceride or free fatty acid), the specific arrangement of the saturated and unsaturated fatty acids on the glycerol backbone, the composition of the free fatty acid, the composition of the diet, the type and quantity of triglycerides supplemented in the diet, the intestinal flora, the sex and age of the birds (Renner \& Hill, 1961; Leeson \& Summers, 2001, Nascif et al., 2004).

\begin{tabular}{lccccc}
\hline $\begin{array}{l}\text { Table 2 } \text { - Energetic values (kcal/kg) of different vegetal oils and } \\
\text { animal fats. }\end{array}$ & \multicolumn{1}{l}{ Gross energy } & ME$^{1}$ & ME $^{2}$ & AME & TME \\
Oil/fat & 9.231 & 7.800 & 8.100 & - & - \\
Acid Soybean & 9.438 & - & - & 8.826 & 9.130 \\
Canola & 9.229 & 6.500 & 7.800 & 8.330 & - \\
Coconut & 9.400 & - & - & - & 8.817 \\
Dende & 9.390 & - & - & 8.886 & 9.250 \\
Corn & - & 7.200 & 8.000 & - & - \\
Palm & 9.415 & - & - & 8.790 & 9.200 \\
Soybean (OSD) & 9.334 & 8.200 & 9.000 & 8.817 & 9.159 \\
Poultry Fat & 9.322 & & & 7.594 & - \\
Lard & 9.414 & 7.400 & 8.000 & 7.374 & 8.116 \\
Beef tallow & - & 8.600 & 9.000 & - & - \\
Fish & 9.367 & - & - & 8.216 & - \\
OSD+ bovine (1:1) & 9.142 & - & - & 8.082 & - \\
OSD+ coconut (1:1) & 9.142 & &
\end{tabular}

OSD = degummed soybean oil. $\mathrm{ME}^{1}=$ birds until 3 weeks. $\mathrm{ME}^{2}=$ birds after 3 weeks. $\mathrm{AME}=$ apparent metabolizable energy. $\mathrm{TME}=$ true metabolizable energy. Source: adapted from Butolo (2002); Nascif et al. (2004); Lara (2004)

\begin{tabular}{lcc}
\hline $\begin{array}{l}\text { Table } \mathbf{3} \text { - Digestibility of vegetal oils according to bird age } \\
\text { (weeks). }\end{array}$ & \\
Oil Digestibility & $\mathbf{3 - 4}$ weeks & $\mathbf{8}$ weeks \\
Acid soybean & 88 & 93 \\
Acid corn oil & 90 & 92 \\
Corn oil & 84 & 95 \\
Soybean oil & 96 & 96 \\
\hline
\end{tabular}

Source: Adapted from Leeson \& Summers (2001)

The lipids arrive intact in the duodenum. The presence of food in the duodenum stimulates the secretion of cholecystokinin, which induces the contraction of the gall bladder and the secretion of the pancreatic juice, making the chyme. Colipase binds to the oil-water interface and produces the emulsion. Afterwards, triglycerides undergo hydrolysis under the action of the pancreatic lipase, and micelles are formed by monoglycerides, diglycerides and free fatty acids.

Micelles are able to solubilize high amounts of fatty acids of low polarity and fat-soluble vitamins. Monoglycerides and long-chain unsaturated fatty acids when linked to the conjugated bile salts promptly form the micelles, whereas saturated fatty acids have less ability to form micelles due to their characteristic low polarity. Since long-chain unsaturated fatty acids have greater ability to form micelles, they may act synergistically in the absorption of saturated fatty acids when mixed with them (Ferreira, 1999).

Once inside the enterocytes, monoglycerides and free fatty acids are re-esterified and combined with free and esterified cholesterol, lipoprotein and phospholipids to form the so-called lipoproteins or chylomicrons or still portomicrons. Thus, re-esterified triglycerides are taken from the digestive system to the circulatory system of the bird in this form (Leeson \& Summers, 2001).

As the lymphatic system of the birds is not well developed, the absorption route of the lipids is through the portal venous system. Very Low density lipoproteins (VLDL) are quantitatively more important in birds, particularly during the laying period, because they are the proteins that carry fat from the liver to the extrahepatic tissues, as for example, to the ovary, where they will be used for egg yolk synthesis. Triglycerides that are not utilized in the liver or not incorporated into the egg yolk are utilized in other tissues (heart, muscle) or are stored in the adipose tissue (Escribano, 1991).

During absorption and transportation processes, no alterations occur in the composition of fatty acids. Therefore, there is a great similarity between the dietary fat fed to birds and the body fat that is deposited. Triglycerides can be synthesized from the glucose resulting from the digestion of the carbohydrates. The composition of the fat synthesized through this route is characterized by an elevated content of palmitic acid, estearic acid, and oleic acid, which constitute $90 \%$ of the total fatty acids. The presence of fat in the diet inhibits the synthesis of fat from carbohydrates. The final composition of body fat is a pondered average among the fat produced endogenously from glucose, the quantity and composition of the fatty acids in the diet and the fat resulting from catabolism through $\beta$-oxidation (Ajuyah et al., 1991; Ferreira, 1999, Sanz et al., 2000b).

Carew et al. (1972) evaluated the absorption of corn oil and tallow in light male birds and observed that absorption of both fats was lower in younger birds. The capability to absorb corn oil increased from 84 to $95 \%$ from the first to the second week of age and absorption of tallow has increased from 40 to $79 \%$. These results indicated that newly hatched chicks do not have complete physiological ability to absorb fat. Nevertheless, this ability develops quickly after the first days of life. 
Broiler breeder males showed lower apparent digestibility of fat in the first week of life than in the second and third weeks of age (Mahagna et al., 1988).

Despite the existing contradictions in the literature and the common sense between the nutritionists that the chicks on the first days of age are not able to digest oils, Zelenka et al. (1997) has used $2.9 \%$ and $3.3 \%$ of ether extract in the diet in two experiments and demonstrated that the apparent digestibility of the fat is high during the first week of age, low on the second and high after the third week of life.

Noy and Sklan (1995) studied the digestion and absorption of fats in young birds (from 1 to 21 days) and have reported that the true digestibility of the unsaturated fat in four-day-old birds was higher than $85 \%$, increasing a little on the subsequent days. This demonstrates that the activity of lipases and bile salts on the fourth day of age were enough for the complete fat digestion. It was concluded that fat digestibility is not a limiting factor for the growth of young birds.

According to Freitas (1999), broilers show high digestibility of fat on the first week of life and the inclusion of oil in the initial diet promotes a better performance of the chickens until 21 days of age.

During the first three weeks of age, chicks fed diets with oil have shown higher apparent digestibility values of ether extract than the ones that received rations without oil (Cançado, 1999).

\section{Quality of the lipids}

Oxidative rancidity occurs due to the oxidation of double bonds in unsaturated fatty acids, forming peroxides or hydro-peroxides that later polymerize and decompose with the production of aldehydes, ketones, and low molecular weight acids. The process of oxidative rancidity or peroxidation and the consequent rancidification is the major cause of loss of quality of the ingredient or ration. It affects flavor, aroma, color and texture, and also decreases the nutritive value. Moreover, fat-soluble vitamins are destroyed by this process, especially vitamins A and E (Shermer, 1990).

Particularly oils and fats composed by unsaturated fatty acids suffer the attack of free radicals. The chemical structure allows the removal of a hydrogen atom from a $\mathrm{CH}$ group of the carbonic chain and consequently a free radical is formed, starting a lipidic peroxidation process. This reaction may occur at environmental temperatures, but can be rapidly increased on the presence of catalyzers such as other peroxides, copper, iron, nickel, cadmium, zinc, high temperatures and light. The combination of several free radicals of fatty acids produces a huge variety of stable final products: hydrocarbons, aldehydes, ketones, alcohols, and organic acids (Menten et al., 2003).

Hydrolytic rancidification results in the development of undesirable flavor due to the hydrolysis of the triglycerides that compose fats or oils as a result of the action of lipolytic enzymes present in the fats or produced by certain microorganisms.

\section{- Antioxidants}

An antioxidant can be defined as a chemical compound or substance that inhibits oxidation, or as any substance that diminishes or inhibits oxidation when present in lower concentrations than the oxidable substrate. From the biological point of view, antioxidants are defined as compounds that completely protect the biological systems against the harmful effects or reactions that cause the oxidation of macromolecules or cellular structures (Abdala, 1993 cited by Gòmez, 2003).

Both synthetic and natural antioxidants are included in several foods, especially in those containing oils and fats. The lipids of foods and particularly foods that contain polyunsaturated fatty acids are easily oxidized (chain reaction). The natural antioxidants (vitamins A and $E$ ), the synthetic $\alpha$-tocopherol and other phenolic antioxidants (BHA - Butyl hydroxyanisole, BHT - Butyl hydroxytoluene, TBHQ - tert-butyl-hydroxyquinone, PG - 3,4,5-Trihydroxybenzoic acid propyl ester) and the non-phenolic antioxidants (Ethoxyquin - Ethox, 6 ethoxy-1,2 dihydro-2,2,4 trimethyl quinoline) are effective in inhibiting oxidation. BHA and BHT are effective in stabilizing animal fats. TBHQ is effective in stabilizing both animal and vegetal fats. The mixture of TBHQ with BHT and/or BHA is widely used in the control of oil and fat oxidation. PG is the most adequate to stabilize animal fats (Butolo, 2001; Papas, 1993 cited by Gómez 2003).

\section{- Quality control}

Several analyses can be used to determine the oxidative profile of ingredients and rations. The following methods are used to evaluate the quality of oils or fats: titration, moisture, insoluble, unsaponifiable matter, percentage of fat, percentage of free fatty acids/acidity and the fatty acid profile (Huyghebaert et al., 1988 and Shermer, 1990). Methods specific to evaluate oxidative stability are initial peroxide values, active oxygen method (AOM), oil stability index (OSI), iodine values and thiobarbituric acid reactive substances (TBARS). 


\section{- Moisture}

Moisture is determined by the weight percentage of the lipidic source after drying at $105^{\circ} \mathrm{C}$ for 4 hours. Maximum accepted values are between 0.5 and $1.0 \%$, since moisture interferes directly with the energy content (Butolo, 2002).

\section{- Impurities}

Impurity is calculated as the percentage of the insoluble fraction of the lipid in petroleum ether at temperatures between $40-60^{\circ} \mathrm{C}$. Impurity contents should be lower than $1 \%$.

\section{- Percentage of free fatty acids or acidity}

This analysis measures the percentage of free fatty acids and it may be performed using two different methods. The first method uses $\mathrm{NaOH}$ to titrate oleic acid, which predominates in animal fats. Results are expressed as $\mathrm{mg}$ of $\mathrm{NaOH} / \mathrm{g}$ of diet or fat. The second method uses $\mathrm{KOH}$ in titration and the results are expressed in $\mathrm{mg}$ of $\mathrm{KOH} / \mathrm{g}$ of fat or ration. It has been suggested that for each $1 \%$ of increase in acidity, 10 $\mathrm{kcal}$ of metabolizable energy is lost per $\mathrm{kg}$ of diet/ ingredient (Barbi \& Lucio, 2003).

\section{- Unsaponifiables}

Steroids, pigments and hydrocarbons that form soaps when mixed with caustic soda comprise the unsaponifiable matter. These substances are indigestible and are soluble in common solvents for oils. Therefore, the higher their percentage, the lower is the energetic value of the oil or fat. It is assessed as the material extracted from the lipid source using diethyl ether after ethanolic alkaline saponification. The maximum level admitted in oils and fats is $1 \%$ (Butolo, 2002).

\section{- Saponification value}

This value is obtained by the quantity of $\mathrm{KOH}(\mathrm{mg})$ needed to saponify $1 \mathrm{~g}$ of oil or fat. The saponification value is higher when trygliceride chains are shorter. Therefore, each type of lipid has its own reference value (Butolo, 2002).

\section{- Fatty acid profile}

The composition of the fatty acids of lipids is determined by the separation of the methyl esters of the fatty acids using gas chromatography (Barbi \& Lúcio, 2003). The profile of fatty acids is of importance to the quality of the utilized lipid and to the absorption of these lipids by the bird, and also because it influences the quality of the fat deposited on the broiler carcass.

\section{- Peroxide values}

This method is used to evaluate the quality of oils, fat and sub-products with high percentage of fat. Peroxides are unstable intermediate substances, and their concentration has a typical normal curve. Afterwards, the peroxide formation rate decreases while the decomposition of secondary products (not indentified in this test) continues, therefore the importance of not performing this test only in one moment (Shermer, 1990).

\section{- Active oxygen method (AOM)}

In this evaluation, a tube containing $2.0 \mathrm{ml}$ of fat is placed in a water bath with controlled temperature $\left(97.8^{\circ} \mathrm{C}\right)$ and air bubbling at a rate of $2.33 \mathrm{ml}$ per tube /second. After 20 hours, the contents of peroxide are measured. The maximum acceptable is 20 meq of peroxide per kilogram of fat. AOM results might be related to the stability of the fat or the ration. One of the advantages of this test is the ability to assess the relative effectiveness of different antioxidants.

\section{- OSI}

The test of oxidative stability has a similar principle to AOM. A sample of fat is placed into the equipment at a temperature higher than $100^{\circ} \mathrm{C}$ in the presence of oxygen. This test measures the induction period, which is the time needed to degrade organic acids derived from aldehyde and ketones, as well as the time needed to concentrate peroxide products in the solution (Barbi \& Lúcio, 2003).

\section{- lodine values}

This method is frequently used to measure fat stability. The iodine value estimates the number of double bonds present in the fat or oil. Consequently, it is necessary to previously know the nature of the lipid and the number of double bonds that might be present in the lipid. Bird fats should have iodine values between 70 and 75 . The higher the extension of the oxidation, the lower is the iodine value of the sample. This analysis has the same limitations of the method of initial value of peroxides. Moreover, high levels of peroxide might interfere with the procedure.

\section{- Analysis of the thiobarbituric acid (TBARS)}

This analysis quantifies the concentration of malonaldehyde formed by the oxidation of a triglyceride. Malonaldehyde is a product of the oxidation of the peroxides that are formed initially. 
Nevertheless, one of the great limitations of this method is the fact that oxidation can be potentially advanced before malonaldehyde is produced. In addition, malonaldehyde is only one of the several products derived from the decomposition of peroxides.

\begin{tabular}{|c|c|c|c|c|c|c|c|c|}
\hline Parameters & & Unit C & Crude soy oil & Degummed soybean oil & Acid soybean oil & Olive oil & Palm oil & Linseed Oil \\
\hline Moisture & Max & $\%$ & 0.50 & 0.50 & 1.0 & & 0.40 & 0.50 \\
\hline Total fatty acids & Min & $\%$ & 98.0 & 98.0 & 30 & & 98.0 & 98.0 \\
\hline Unsaponifiable matter & Max & $\%$ & 1.5 & 1.5 & 2 & - & 1.20 & 1.50 \\
\hline Saponification value & & $\%$ & $189-195$ & $195-198$ & $195-198$ & $187-195$ & $195-205$ & $188-198$ \\
\hline lodine value & & $\mathrm{g} / 100 \mathrm{~g}$ & $120-140$ & $125-135$ & $115-125$ & $79-89$ & $44-58$ & 170 \\
\hline Peroxide & Max & $\mathrm{meq} / 1000 \mathrm{~g}$ & 5.0 & 3.0 & - & & 5.0 & 6.0 \\
\hline Total acidity & & $\%$ & 3.0 & 3.0 & - & $0.25-3$ & - & 3.0 \\
\hline Density & & $\mathrm{g} / \mathrm{ml}$ & 0.92 & 0.93 & 0.93 & $0.909-0.913$ & - & - \\
\hline Color & & & amber & amber & Dark-brown & & - & amber \\
\hline
\end{tabular}

Source: Compêndio Brasileiro de alimentação animal (2000).

\begin{tabular}{|c|c|c|c|c|c|c|}
\hline Parameters & & Unity & Poultry & Beef Tallow & Lard & Fishes \\
\hline Moisture & $\operatorname{Max}$ & $\%$ & 0.50 & 0.50 & 0.50 & - \\
\hline Total fatty acids & Min & $\%$ & 90 & 94 & 94 & - \\
\hline Free fatty acids & & $\%$ & 8 & 4 & 4 & - \\
\hline Unsaponifiable matter & $\operatorname{Max}$ & $\%$ & 1.0 & 1.5 & 1.5 & - \\
\hline Saponification value & & $\%$ & $190-196$ & $190-202$ & $190-194$ & $186-190$ \\
\hline lodine value & & $\mathrm{g} / 100 \mathrm{~g}$ & $75-85$ & $35-45$ & $55-65$ & $125-180$ \\
\hline Peroxide value & Max & $\mathrm{meq} / 1000 \mathrm{~g}$ & 10 & 10 & 10 & - \\
\hline
\end{tabular}

Source: Fedna (1999); Compêndio Brasileiro de alimentação animal (2000).

\section{VEGETAL OILS}

\section{Cotton oil}

The utilization of cotton oil is limited by the presence of the natural yellow pigment denominated gossypol, which is a toxic or anti-nutritional element. It causes iron deficiency and lysine unavailability due to Maillard reactions, thus reducing the nutritional value of proteins (when utilized in the meal form). Ferrous sulphate must be added to broiler diets in which cotton oil is included, because it chelates gossypol, preventing its absorption in the digestive tract and thus neutralizes its deleterious effects. Broilers tolerate levels higher than 100 ppm of free gossypol without performance impairment. It is not recommended to use gossypol in laying hen diets. The presence of cyclopropenoic fatty acids (malvalic and sterculic) intensifies the effects of gossypol, resulting in green yolk and pink coloration of the albumen. When high amounts of these fatty acids are ingested, the yolk develops redness and viscous appearance after short time of refrigeration. This alteration is caused by the increase in the concentration of saturated fatty acids in the yolk as a function of the inhibition of the enzymes $\Delta^{6}$ e $\Delta^{5}$ desaturase, which hinders the denaturation of stearic and palmitic acids and their corresponding monounsaturated fatty acids. Besides the ability of changing the composition of yolk fatty acids, the cyclopropenoic fatty acids alter the permeability of the vitelline membrane and cause iron diffusion from the yolk to the albumen, where ovotransferrin acts as iron chelator. This reaction between ovotransferrin and iron is responsible for the pink coloration of the albumen. On the other hand, some ovotransferrin may diffuse to the yolk, combine with iron and also cause red yolk coloration. The pink albumen coloration is seen more often in eggs stored for long periods of time. In breeder flocks, besides yolk discoloration, high levels of gossypol and the diffusion of ovotransferrin can reduce egg hatchability (Leeson \& Summers, 2001; Butolo, 2002).

\section{Canola oil or Rapeseed oil}

Canola is the name given to rapeseed that contains less than $2 \%$ of erucic acid (docosenoic acid, C22:1, $\omega-9)$ in relation to the total fatty acid and less than 30 umoles of glucosinolates per gram of free oil on seed dry matter basis (Leeson \& Summers, 2001).

In birds, the adverse effects of adding erucic acid to the diets are reflected on intake, growth and the apparent digestibilities of total lipid and individual fatty acids (Sim et al., 1985 cited by Leeson \& Summers, 2001). Furthermore, chicks fed with diets containing erucic acid 
deposit less fat and utilize energy from this lipid less frequently (Renner et al., 1979 cited by Leeson \& Summers, 2001).

Female broilers fed diets containing two different forms of canola oil showed better growth rate when compared to females fed diets containing tallow and acidulated soybean oil soapstock. This observation confirms the advantage of using vegetal oils instead of tallow and acidulated soybean oil soapstock as energy sources for birds. The better growth rates are a result from the higher percentage of long chain fatty acids and higher contents of triglycerides (Thacker et al., 1994).

Andreotti et al. (2001) observed similar performance, carcass yield and cut yields of broilers with 49 days old fed poultry fat, canola, sunflower, corn, soybean or lard

To evaluate the effects of different lipidic sources on the physical and chemical characteristics of thigh meat, broilers were fed diets containing soybean oil, sunflower oil, canola oil, corn oil, poultry fat or lard. Lard and corn oil resulted in more red-colored meat when compared to the meat of birds fed with oil of canola, sunflower or soybean, but did not differ from the poultry fat (Souza et al., 2001).

\section{Sunflower oil}

Alao \& Balnave (1984) reported better development and feed conversion of birds fed with diets containing sunflower oil when compared to birds fed olive oil. It was suggested that the difference was a function of the fatty acid composition of the different vegetable oils.

Sanz et al. (1999) fed broilers with sunflower oil or a mixture of beef tallow/lard and the utilization of saturated fats resulted in greater abdominal fat deposits than unsaturated fats.

According to Sanz et al. (2000a), the utilization of a source of unsaturated lipids reduces fat and increases protein on the broiler carcasses. The difference in protein accretion was attributed to the level of saturation of the fat, since the energy derived from unsaturated fat may be used for other metabolic purposes, whereas the energy derived from saturated sources is less promptly utilized and accumulates as body fat. In general, corporal fat accumulation may be considered the result of the balance between the fat absorbed from the diet, the endogenous synthesis of fat (lipogenesis) and the catabolism of fat by $\beta$-oxidation (lipolysis).Therefore, in cases in which the quantity of absorbed fat is the same, lower fat depositions may be attributed to an increase in catabolism or endogenous decrease in the synthesis of fatty acids, or both.

Sanz et al. (2000b) evaluated inclusion levels of $8 \%$ of two lipid sources, one saturated (beef tallow) and one unsaturated (sunflower oil). There was a significant reduction in the abdominal fat of birds fed diets with sunflower oil (Becker et al., 1979 cited by Sanz et al., 2000b). Provided that the quantity of absorbed fat was higher in birds fed diets containing sunflower oil, the reduction in the fat deposit of these birds seemed to be a function of higher fat oxidation rates (catabolism) and lower synthesis of fatty acids.

Using $8 \%$ of inclusion of three lipidic sources (sunflower oil, fish oil and beef tallow) in broiler feeding, Newman et al. (2002) observed a higher proportion of linoleic acid and higher polyunsaturated/saturated ratio in the composition of the fat of birds fed with sunflower oil.

\section{Linseed oil}

The effects of soybean, canola, sunflower and linseed oils on the nutritive and organoleptic traits of the meat and the profile of fatty acids were evaluated in 5-week-old broilers (López-Ferrer et al., 1999). The parameters of meat quality were not different between treatments, even though meat juiciness of the samples from birds fed with canola oil has been inferior to the other treatments. The values of TBARS were higher in fresh abdominal fat of birds fed linseed oil and soybean oil and in the breast muscle stored for 12 months when compared to the samples of fresh breast. Higher levels of omega-3 in both tissues were observed in birds fed linseed oil.

Rosa (1999) used three types of oils (linseed, soybean and a mixture of linseed and fish) at inclusion levels of 1,2 and $3 \%$ in broiler diets and observed that the composition of fatty acids of the rations influenced the fatty acid profile of the breast and thigh.

It has been suggested that the size of fat deposits may be changed according to the fatty acid profile of the diet. The use of beef tallow, olive oil, sunflower oil and linseed oil in broiler diets evidenced that fat sources rich in polyunsaturated fatty acids produce less fat deposits than the ones rich in saturated or monounsaturated fatty acids (Crespo \& Esteve-Garcia (2002ab).

\section{Palm oil}

According to Rodriguez et al. (2002), palm oil or mixtures of palm oil, fatty acids distilled from the palm 
and calcic soap are sources of vegetal oils with a fatty acid profile that might replace animal fats without any kind of negative impact on carcass quality.

\section{Soybean oil}

The raw soybean oil has on its composition several substances considered as impurities (Table 6) that must be removed using several processes (filtration, hydration and degum). These substances are solid residues from the extraction process, and they are phospholipids, gums, metallic complexes, free fatty acids, peroxides, polymers, secondary products from oxidation and pigments (Beauregard et al., 1996).

\begin{tabular}{lc}
\hline Table 6 -Composition of the raw soybean oil. & Levels \\
Components & 95 to $97 \%$ \\
Triglycerides & 0.3 to $1.1 \%$ \\
Free fatty acids & 1.5 to $25 \%$ \\
\hline Phospholipids & 30 to $150 \mathrm{ppm}$ \\
Metals & 50 to $1200 \mathrm{ppb}$ \\
Chlorophyll & 0.06 to $0.15 \%$ \\
Tocopherols & 0.3 to $0.5 \%$ \\
Sterols & 0.01 to $0.02 \%$ \\
\hline Hydrates of carbon
\end{tabular}

Source: Adapted from Beauregard et al. (1996).

\section{Degummed Soybean oil}

The degummed soybean oil is a product obtained from the raw oil after degumming, which consists of centrifugation the soybean oil to separate it into the two following parts: degummed oil and unsaponifiable matters (Compêndio Brasileiro de Alimentação Animal, 2000).

Scaife et al. (1994) fed female broilers with rations containing different sources of lipids (beef tallow, soybean oil, canola oil, marine fish oil or a mixture of these oils) and observed that live weight was significantly higher when soybean oil was used. Birds fed with canola oil also showed higher intake and higher weight. Birds fed beef tallow had the poorest conversion rate.

Vieira et al. (2002) evaluated broiler rations containing 0,4 and $8 \%$ of soybean oil and acidulated soybean oil soapstock, and observed similar weight gain between the different lipidic sources and improved feed conversion in birds fed with soybean oil in comparison to the birds fed with acidulated soybean oil soapstock. They also observed a reduction in feed intake of birds fed with acidulated soybean oil soapstock when the inclusion level was increased from 4 to $8 \%$, whereas no reduction in feed intake was observed in birds fed with soybean oil.
Lara et al. (2003) fed male broilers with different lipidic sources (degummed soybean oil, poultry fat, acidulated soybean oil soapstock, a mixture of poultry fat/soybean oil and other mixture of soybean oil/ acidulated soybean oil soapstock). It was observed better weight gain and intake in birds fed with soybean oil in relation to the birds fed with acidulated soybean oil soapstock. The different lipidic sources had no influence on the levels of moisture, ether extract, and protein of the breast, thigh and whole carcasses.

According to Moura (2003), the inclusion of soybean oil in broiler diets does not affect the moisture and ether extract in the breast and thigh muscles. Furthermore, the deposition of fat on the breast muscle and viscera is not affected by the inclusion of the oil in the diet.

\section{Acidulated soybean oil soapstock}

The acidulated soybean oil soapstock, also denominated as soybean fatty acid, is a sub-product of the industry of soybean oil. This sub-product is obtained through the alkaline neutralization of the raw oil, which produces a raw soap (a mixture of soaps, neutral oil, water, sterols, pigments, and other constituents). This unstable product is converted in acidulated soybean oil soapstock after a treatment of sulfuric acid in hot aqueous solution. Compared to soybean oil, acidulated soybean oil soapstock contains high levels of free fatty acids (50\%), unsaponifiable matter, and oxidized fatty acids, besides being also rich in carotenoids (Bornstein \& Lipstein, 1963; Lipstein et al., 1965; Pardio et al. (2001).

Free fatty acids affect absorption negatively and, consequently, also the nutritive value of the fats. The ratio between free fatty acids and intact triglycerides is important, since supplements with free fatty acids are absorbed less efficiently than the free fatty acids in form of triglycerides. The reason for this is that monoglycerides are essential to incorporate insoluble fatty acids in the micellar complex. There are not enough monoglycerides to combine with all free fatty acids when they are offered as the only fat source and absorption is then impaired (Fats in animal feeds, 1985; Blanch et al., 1995).

Wiseman \& Salvador (1991) worked with diets for broilers supplemented with 3 different sources of lipids (tallow, soybean oil and palm oil) and their respective acid oils, with different levels of free fatty acids. The reduction in metabolizable energy values of the fats with higher contents of free fatty acids tend to be more pronounced with greater inclusion levels of lipids. Besides, reduction is also greater with greater 
saturation levels. The increase in free fatty acid levels reduces progressively the ME values of the energy source, and such effect is more pronounced in young birds.

The use of refined soybean oil, raw soybean oil or acidulated soybean oil soapstock showed an increase on the levels of linoleic fatty acid on the carcass of birds fed with refined soybean oil and raw soybean oil in relation to the acidulated soybean oil (Cascabulho, 2000).

The value of nitrogen-corrected metabolizable energy of acidulated soybean oil soapstock $(8.144 \mathrm{kcal} /$ $\mathrm{kg} \mathrm{DM}$ ) determined for 28-day-old broilers was 5\% inferior than the value of raw soybean oil. The inclusion of acidulated soybean oil soapstock in rations for animals depends on the maintenance of a minimum of quality control, so that the product has surely not been adulterated by the inclusion of other low-quality oils (Vieira et al., 2002).

The values of nitrogen-corrected metabolizable energy of the acidulated soybean oil soapstock suggested for young and adult birds were 7.788 and $8.610 \mathrm{cal} / \mathrm{kg} \mathrm{DM}$, respectively (Freitas et al., 2002).

\section{Animal fats}

Deaton et al. (1981) used diets with similar nutritive values added with 4, 7 and $10 \%$ of animal fat, and observed that the increasing fat level of the diet increased the quantity of abdominal fat, corroborating results reported by Yalçin et al. (1998).

\section{Poultry fat}

Poultry fat is also known as viscera oil and is obtained after the extraction of fat by autoclaving or in a percolator tank and expeller. After extraction, the fat is placed into a decantation tank to extract the acidulated soapstock and moisture excess. At this point, it is ready to be used in ration or to be refined (Neto, 1994). Product yield varies from 1.3 to $1.6 \%$ of the live weight of the bird (Mano et al., 1999). This range depends on the level and source of energy used in the ration, besides bird sex, age and weight at slaughter. Higher percentages of fat are obtained when higher levels of energy are used, older birds are slaughtered and consequently with higher live weight; moreover, females produce more fat than males, independent of dietary energy level and age at slaughter.

Assessing the effects of the mixtures of vegetal and animal fats, corn oil and poultry fat on the proportions of $0,3,6$ and $9 \%$ in the alimentation of broilers, Griffiths et al. (1977) observed that the birds fed with corn oil and poultry fat were significantly heavier than birds non-supplemented with fat.
Weight gain, feed intake and feed conversion of broilers fed with diets containing $4 \%$ of poultry fat, $4 \%$ of soybean oil or a mixture of $2 \%$ of soybean oil and $2 \%$ of poultry fat were not affected by oil sources (Dutra Jr et al., 1991). However, there was a decrease in feed intake and weight when the mixture was used.

The effects of increasing inclusion levels $(0,2,4,6$, 8 and $10 \%)$ of refined palm oil $(8,000 \mathrm{kcal} / \mathrm{kg} \mathrm{ME})$, palm oil $(8,500 \mathrm{kcal} / \mathrm{kg} \mathrm{ME})$, corn oil $(9,000 \mathrm{kcal} / \mathrm{kg} \mathrm{ME})$ and poultry fat $(9,000 \mathrm{kcal} / \mathrm{kg} \mathrm{ME})$ in diets for broiler were studied by Valencia et al. (1993). There were no effects of the sources of oil on weight gain and feed conversion. On the other hand, performance was proportionally better with increasing inclusion levels of the oil sources.

Performance parameters were evaluated in broilers fed different lipidic sources (raw soybean oil, poultry fat and acidulated soybean soapctock and its mixtures). There were no significant differences in weight gain, feed intake, feed conversion and viability when soybean oil and poultry fat were used (Lara et al., 2003)

The effects of the oxidized poultry fat on the values of metabolizable energy for broilers from 31 to 34 days old was evaluated by Racanicci et al. (2000). Oxidized poultry fat is produced by heating from 80 to $90^{\circ} \mathrm{C}$, with constant aeration for 40 days. The birds fed with rations containing $10 \%$ of fresh poultry fat or oxidized poultry fat showed apparent metabolizable energy and apparent adjusted energy for nitrogen values of 9,240, $9,150,7,700$ and $7,595 \mathrm{kcal} / \mathrm{kg}$, respectively.

According to Edwards et al. (1973), the inclusion of poultry fat in broiler diets resulted in an increase in the deposition of oleic acid and a reduction in the levels of the linoleic acid in the adipose tissue of the birds. The use of cotton oil or acid cotton oil increased the deposition of linoleic acid. Similar results were obtained by Lara et al. (2003), who observed a higher deposition of monounsaturated fatty acids on the carcass of broilers fed with poultry fat when compared to birds fed with raw soybean oil and acidulated soybean oil soapstock.

\section{Beef tallow}

Newman et al. (2002) fed broilers with $8 \%$ of sunflower oil, fish oil or beef tallow in the diet and observed poorer feed conversion in the birds fed with beef tallow.

There was a positive relationship between the composition of the fatty acid present in diet and the composition of the fatty acid of the breast, thigh and 
skin of broilers fed corn oil, beef tallow or a mixture of both (Marion \& Woodroof, 1963).

The type of fat added to the diet has a significant influence on the profile of fatty acids of the abdominal fat, and birds fed tallow have shown higher concentrations of saturated fatty acids and lower concentrations of unsaturated fatty acids comparing to the birds fed with acidulated soybean oil soapstock (Thacker et al., 1994).

Sanz et al. (1999) formulated broiler diets containing sunflower oil and bovine/swine fat and reported that the inclusion of saturated fats produced higher accumulation of intramuscular fat and abdominal fat.

In a study using one saturated (beef tallow) and one unsaturated (sunflower oil) lipid source at $8 \%$ of inclusion, Sanz et al. (2000b) observed a significant reduction in the deposit of abdominal fat in the birds that received diets with sunflower oil.

According to Crespo \& Esteve-Garcia (2002b), the location of fat deposition depends on the kind of fatty acid added to the diet (saturated and polyunsaturated). Birds fed with diets rich on animal saturated fatty acids tend to have proportionally larger abdominal and mesenteric fat than other fat deposits.

\section{Lard}

Working with broilers fed diets containing sunflower oil and mixture of bovine tallow/swine fat, Sanz et al. (2000a) did not observed effects of the lipidic sources on feed intake, weight gain and feed conversion of the birds.

No effects on performance was observed when broilers were fed from 21 to 49 days with diets containing one of the following lipid sources: poultry fat, refined soybean oil, refined canola oil, refined sunflower oil, lard and refined corn oil (Andreotti et al., 2001).

Souza et al. (2001) evaluated six different lipid sources in rations for broilers and observed that the meat of birds fed with lard presented a more pronounced red coloration in relation to the meat from birds fed with soybean oil, sunflower oil and canola oil, but it was not different from birds fed poultry fat.

\section{Fish oil}

Fish oil is produced by the compression of whole fishes and sub-products for industries of fishery. This kind of oil contains high percentages of long-chain polyunsaturated fatty acids, which accounts for the oxidative instability and the transference of characteristic fish flavor to the meat of animals fed fish oil. In general, fish oils are rich sources of omega3 fatty acids and poor sources of omega- 6 , and the contents of linoleic acid are also low $(<2 \%)$. The fatty acid profile of the different oils varies with the period of the year, processing method and predominant fish species that was captured (Fedna, 1999).

Some authors reported the unpleasant flavor of fish in the meat of broilers fed with $1.5 \%$ to $2.5 \%$ of fish oil (Hardin et al.,1964; Miller \& Robisch, 1969).

Phetteplace \& Watkins (1990) evaluated different relations of poultry fat and fish oil (Menhaden) in broiler feeding. Birds fed with diets containing more fish oil have deposited more quantities of unsaturated fatty acids in the abdominal fat, as well as more n-3 fatty acids. On the other hand, both total n- 6 fatty acids and the relation of $n-6: n-3$ were higher in the abdominal fat of birds fed with rations containing higher quantities of poultry fat.

Chanmugam et al. (1992) also demonstrated that the content of $\omega-3$ fatty acids in the thigh of broilers might be increased by the addition of linseed oil or fish oil in the diet (Menhaden). Therefore, it has been suggested the inclusion of low dietary levels of fish oil together with another source of linoleic fatty acid to obtain an acceptable product with increased ratio between $\omega-3: \omega-6$ fatty acids.

Scaife et al. (1994) have utilized beef tallow, soybean oil, colza oil, oil of marine fish or mixtures of these oils in female broiler diets. The relation $\omega-6: \omega-3$ was significantly increased with the inclusion of soybean oil and decreased with the inclusion of marine fish oil.

Rosa (1999) observed that the composition of fatty acids of the rations has influenced the profile of fatty acids of the breast and thigh using linseed oil, soybean oil and a mixture of linseed plus fish oil at inclusions levels of 1,2 an $3 \%$ in diets for broilers.

Diet inclusion of $8 \%$ of sunflower oil, fish oil or beef tallow resulted in lower deposition of corporal fat on birds fed with fish oil and sunflower oil. It was concluded that feeding broilers with sources of $n-3$ and n- 6 produced less carcass fat, and also improved feed conversion. The results are interesting both from an economical point of view and from the point of view of the health of consumers (Newman et al., 2002).

\section{REFERENCES}

Ajuyah AO, Lee $\mathrm{KH}$, Hardin RT, Sim JS. Influence of dietary full-fat seeds and oils on total lipid, cholesterol and fatty acid composition of broiler meats. Canadian Journal of Animal Science 1991; 71: 1011-1019. 
Alao SJ, Balnave D. Growth and carcass composition of broiler fed sunflower and olive oil. British Poultry Science 1984; 25:209-219.

Andreotti MO, Junqueira OM, Cancherini LC, Rodrigues EA, Sakomura NK. Valor nutricional de algumas fontes de gordura para frangos de corte. In: Anais da $38^{\circ}$ Reunião Anual da Sociedade Brasileira de Zootecnia; 2001; Piracicaba, SP. Piracicaba: SBZ; 2001.

Barbi JHT, Lúcio CG. Qualidade e digestibilidade de gorduras e óleos na alimentação de aves. In: XI Congreso de la Amena yl del Clana; 2003; Cancum, México. p.159-177.

Beauregard L, Moustafa A, Sampaio JM. Puntos críticos a considerar en la refinación de aceites para la producción de grasas y margarinas. Soya Notícias 1996; 16:10-15.

Blanch A, Barroeta AC, Baucells MD, Puchal F. The nutritive value of dietary fats in relation to their chemical composition. Apparent fat availability and metabolizable energy in two-week-old chicks. Poultry Science 1995; 74:1335-1340.

Bornstein S, Lipstein B. Some unusual waste vegetable oils or fat supplements in practical broiler rations. Poultry Science 1963; 42: 172-184.

Butolo JE. Utilização de ingredientes líquidos na alimentação animal. In: Anais do Simpósio sobre Ingredientes na Alimentação Animal; 2001; Campinas, SP. Campinas:Colégio Brasileira de Nutrição Animal, 2001.

Butolo JE. Qualidade de ingredientes na alimentação animal. Campinas:Colégio Brasileiro de Nutrição Animal; 2002. 430p.

Cançado SV. Efeito do jejum pré-alojamento de pintos de corte sobre o desempenho, órgãos digestivos e digestibilidade da ração [tese]. Belo Horizonte: Escola de Veterinária, UFMG; 1999.

Carew LB, Maghemer Jr RH, Sharp Jr RW. Fat absorption by the very young chick. Poultry Science 1972; (3):738-742.

Cascabulho AR. Efeitos de diferentes óleos de soja na composição de gordura da carcaça de frango de corte [dissertação]. Belo Horizonte: Escola de Veterinária, UFMG; 2000.

Chanmugam P, Boudreau M, Boutte T, Park RS, Hebert J, Berrio L, Hwang $\mathrm{DH}$. Incorporation of different types of n-3 fatty acids into tissue lipids of poultry. Poultry Science 1992; 71:516-521.

Compêndio Brasileiro de Alimentação Animal: padronização de matérias primas para alimentação animal. São Paulo: SINDIRAÇÕES/ ANFAL; 2000.

Crespo N, Esteve-Garcia E. Nutrient and fatty acid deposition in broilers fed different fatty acid profiles. Poultry Science 2002; 81: 1533-1542a.

Crespo N, Esteve-Garcia E. Dietary polyunsaturated fatty acids decrease fat deposition in separable fat depots but not in the remainder carcass. Poultry Science 2002; 81:512-518b.

Deaton JW, Mcnaughton JL, Reece FN, Lott BD. Abdominal fat of broilers as influenced by dietary level of animal fat. Poultry Science $1981 ; 60: 1250-1253$.

Dutra Jr WM, Ariki J, Kronka SN, Junqueira OM. Óleo de abatedouro avícola em comparação ao óleo de soja na alimentação de frangos de corte. Revista da Sociedade Brasileira de Zootecnia 1991; 20(5): 471-475.

Edwards HM, Denmamn F, Abou-Ashour A, Nugara D. Influences of age, sex and type of dietary fat supplementation on total carcass and fatty acid composition. Poultry Science 1973; 52:934-948.

Escribano, F. Fisiologia digestiva y metabolismo de las grasas e hidratos de carbono en gallinas ponedoras. In: Nutrición y alimnetación de gallinas ponedoras. Madrid: Ediciones Mundiprensa, 1991

Fats in animal feeds. Illinois: Milk Specialties; 1985. 22p.

Fedna. Normas FEDNA para la formulación de piensos compuestos. Madrid: Ediciones Peninsular; 1999.

Ferreira WM. Digestão e metabolismo dos lipídios. Belo Horizonte: Escola de Veterinária da UFMG; 1999. p.1-34.

Freitas BCF. Digestibilidade da gordura nas primeiras semanas de vida e seu efeito sobre o desempenho do frango de corte [dissertação]. Belo Horizonte: Escola de Veterinária, UFMG; 1999.

Freitas ER, Sakomura NK, Neme R, dos Santos AL. Valores de energia metabolizável do óleo ácido de soja para aves. In: Anais da $39^{\circ}$ Reunião Anual da Sociedade Brasileira de Zootecnia; 2002; Recife, PE.

Gómez MEDB. Modulação da composição de ácidos graxos poliinsaturados ômega 3 de ovos e tecidos de galinhas poedeiras, através da dieta. I. Estabilidade oxidativa [tese]. São Paulo: Universidade de São Paulo; 2003.

Griffiths L, Lesson S, Summers JD. Influence of energy system and level of various fat sources on performance and carcass composition of broilers. Poultry Science 1977; 56:1018-1026.

Hardin JO, Milligan JI, sidwell VD. The Influence of solvent extracted fish meal and stabilized fish oil in broiler rations on performance and on the flavor of broiler. Poultry Science 1964:43 858-860.

Huyghebaert G, De Munter, De Groote G. The metabolizable energy (AMEn) of fats for broilers in relation to their chemical composition. Animal Feed Science Technology 1988; 20:45.

Lara LJC, Baião NC, López CAA, Moura BHS, Ribeiro BRC. Fuentes de aceite en la ración de pollos de carne. In: XVIII Congresso Latinoamericano de Avicultura; 2003; Santa Cruz De La Sierra, Bolívia. CD-ROM.

Lara LJC. Efeito da fonte lipídica em dietas para frangos de corte sobre o desempenho, rendimento e composição da carcaça [dissertação]. Belo Horizonte: Escola de Veterinária, UFMG; 2004.

Leeson S, Summers JD. Nutrition of the chicken. $4^{\text {th }}$ ed. Ontario: University Books; 2001. 413p. 
Lehninger AJ, Nelson DL, Cox MM. Princípios de bioquímica. $2^{\text {nd }}$ ed. São Paulo:Sarvier; 2000. 839p.

Lipstein B, Budowski P, Bornstein S. Effect of autoxidation on the nutritive value of acidulated soybean soapstock in chicks. Poultry Science 1965; 44:1480-1488.

López-Ferrer S, Baucells MD, Barroeta AC, Grashorn MA. Influence of vegetable oil sources on quality parameters of broiler meat. Archiv für Geflügelkunde 1999; 63(1):29-35.

Mahagna M, Said N, Nir I, Nitsan Z. Development of digestibility of some nutrients and of energy utilization in young broiler chickens. In: Proceedings of the XVIII World's Poultry Congress; 1988; Nagaya, JP. p.250-251.

Mano S, Quiroz M, Pardi H, Padilha A. Apostila de tecnologia de aves e derivados. Rio de Janeiro:Faculdade de Veterinária, Universidade Federal Fluminense; 1999.

Marion JE, Woodroof JG. The fatty acid composition of breast, thigh and skin tissues of chicken broilers as influenced by dietary fats. Poultry Science 1963; 42:1202-1207.

Menten JFM, Gaiotto JF, Racanicci AMC. Valor nutricional e qualidade de óleos e gordura para frangos de corte. In: Simpósio sobre Manejo e Nutrição de Aves e Suínos; 2003; Campinas: Colégio Brasileiro de Nutrição Animal; 2003. p.93-135.

Miller D, Robisch P. Effect of herring, menhaden and safflower oils on the $w-3$ and $w-6$ fatty acid content of broiler tissue. Journal of Food Science 1969; 34:136-141.

Moura BHS. Desempenho e composição da carcaça de frangos de corte alimentados com diferentes níveis energéticos com e sem óleo [dissertação]. Belo Horizonte: Escola de Veterinária, UFMG; 2003.

Nascif CCC, Gomes PC, Albino LFT, Rostagno HS. Determinação dos valores energéticos de alguns óleos e gorduras para pintos de corte machos e fêmeas aos 21 dias de idade. Revista Brasileira de Zootecnia 2004; 33(2):375-385.

National Research Council. Nutrient requirements of poultry, $9^{\text {th }}$ ed. Washington: National Academy Press; 1994.

Neto GJ. Qualidade nutricional do subproduto de graxaria avícola. In: Abate e processamento de frangos. Campinas: APINCO; 1994. p. 120

Newman, RE, Bryden, WL, Fleck, E, ASHES, JR, Buttemer, WA, Storlien, LH, Downing, JA. Dietary $n-3$ and n- 6 fatty acids alter avian metabolism: molecular-species composition of breast-muscle phospholipids. British Journal of Nutrition 2002; 88:11-18.

Noy Y, Sklan D. Digestion and absortion in the young chick. Poultry Science 1995; 74(2):366-373.

Pardio VT, Landin LA, Waliszewski KN, Badillo C, Perez-gil F. The effect of acidified soapstock on feed conversion and broiler skin pigmentation. Poultry Science 2001; 80:1236-1239.
Phetteplace HW, Watkins A. Lipid measurements in chickens fed different combinations of chicken fat and Menhaden oil. Journal Agricultural of Food Chemistry 1990; 38:1848-1853.

Racanicci AMC, Menten JFM, Regitano-D'arce M, Gaiotto JB, Longo FA, Pedroso AA, Sorbara JOB. Oxidação lipídica reduz o conteúdo de energia metabolizável do óleo de vísceras de aves para frangos de corte na fase de crescimento. In: Anais da $37^{\circ}$ Reunião Anual da Sociedade Brasileira de Zootecnia; 2000; Viçosa:SBZ; 2000. CDROM.

Renner R, Hill FW. Utilization of fatty acids by the chicken. Journal of Nutrition 1961; 74:259-264.

Rodriguéz MA, Crespo NP, Cortés M, CREUS E, Medel P. Efecto del tipo de grasa de la dieta en la alimentacion del broiler, con enfasis en los productos derivados del aceite de palma. Selecciones avícolas 2002; 44(10):693-702.

Rosa FC. Teor de ácidos graxos poliinsaturados ômega-3 no peito e coxa de frangos de corte alimentados com rações contendo três fontes de óleo [dissertação]. Lavras: Universidade Federal de Lavras; 1999.

Sanz M, Flores A, Perez DE, Ayala P, Lopez-Bote CJ. Higher lipid accumulation in broilers fed on saturated fats than in those fed unsaturated fats. British Poultry Science 1999; 40:95-101.

Sanz M, Flores A, Lopez-Bote CJ. The metabolic use of energy from dietary fat in broilers is affected by fatty acid saturation. British Poultry Science 2000a; 41:61-68.

Sanz M, Lopez-Bote CJ, Menoyo D, Bautista JM. Abdominal fat deposition and fatty acid synthesis are lower and â-oxidation is higher in broiler chickens fed diets containing unsaturated rather than saturated fat. Journal of Nutrition 2000b; 130:3034-3037.

Scaife JR, Moyo J, Galbraith H, Michie W, Campbell V. Effect of different dietary supplemental fats and oils on the tissue fatty acid composition and growth of female broilers. British Poultry Science 1994; 35:107-118.

Shermer WD. Effects of oxidation on the quality of ingredients and feed of poultry. In: 37 Maryland Nutrition Conference; 1990; Maryland. EUA.

Souza PA, Souza HBA, Oba A, Leonel FR, Pelicano ERL, Norkus EA, Junqueira OM, Andreotti MO. Características físicas e químicas da carne da coxa de frangos de corte produzidos com diferentes fontes de óleo. In: Anais da $38^{\circ}$ Reunião Anual da Sociedade Brasileira de Zootecnia; 2001; Piracicaba, SP. Piracicaba: SBZ; 2001.

Thacker PA, Campbell GL, XUY. Composition and nutritive value of acidulated fatty acids, degummed canola oil and tallow as energy sources for starting broiler chicks. Animal Feed and Technology 1994; 46:251-260.

Valencia ME, Watkins SE, Waldroup AL, Waldroup PW. Utilization of crude and refined palm and palm kernel oils in broiler diets. Poultry Science 1993; 72:2200-2215. 
Vieira SL, Ribeiro AML, Kessler AM, Fernandes LM, Ebert AR, Eichner G. Utilização da energia de dietas para frangos de corte formulados com óleo ácido de soja. Revista Brasileira Ciência Avícola 2002; $4(2): 1-13$.

Wiseman J. Fats in animal nutrition. London:Butterworths; 1984.

Wiseman J, Salvador F. The influence of free fatty acid content and degree of saturation on the apparent metabolizable energy value of fats fed broilers. Poultry Science 1991; 70:573-582.

Yalçin S, Ozkan S, Açikgoz Z. Influence of dietary energy on bird performance, cacass parts yield and nutrient composition of breast meat of heterozygous naked neck broilers reared at natural optimum and summer temperatures. British Poultry Science 1998; 39(5):633638.

Zelenka W, Knaus W, Aichinger F, Lettner F. Effects of different dietary fat sources on performance and carcass characteristics of broilers. Animal Feed Science Tecnology 1997; 66:63-73. 